\title{
Nutrient quality and sensory properties of unripe banana based complementary food fortified with crab meat in Nigeria.
}

\author{
Matthew A. Bassey and Ikechukwu E. Ezeagu \\ Department of Medical Biochemistry, College of Medicine, University of Nigeria, Enugu Campus. \\ Corresponding Email: alfredalfred79@yahoo.com. Tel: 2347035016792 \\ DOI: 10.31364/SCIRJ/v9.i01.2021.P0121836 \\ http://dx.doi.org/10.31364/SCIRJ/v9.i01.2021.P0121836
}

\begin{abstract}
Protein-energy malnutrition is increasing among children in developing countries due to low nutrient density of traditional complementary foods. This study investigated the nutrient quality and parameters for acceptability of unripe banana based complementary food fortified with crab, Callinetes amnicola among under-5 Caregivers in Akwa Ibom State. The unripe banana (UB) and crab meat (CM) were processed into flours using standard procedure. The weaning diets were mixed in a ratio of 90:10(UBCM1) and 85:15(UBCM2) of UB and CM respectively. The proximate and mineral compositions of the four samples were determined using standard procedures. A total of 30 Caregivers attending nutrition clinics were purposively selected from 3 health facilities in Uyo LGA for a focus group discussion (FGD). Tape recorder was used to record the FGDs sessions to elicit information from the caregivers using a semi structured questionnaire. Data were analyzed using descriptive statistics with level of significance set at $\mathbf{p}<0.05$. The results showed that availability of raw materials, cost, familiarity and were the key predisposing factors for acceptability. As judged by the result of the sensory evaluation, the control and UBCF had a higher general acceptability scores and significantly different $(\mathrm{p}<0.05)$ compared to other diets. The CM, UB, UBCM1 and UBCM2 have average quantity of protein in the level of $26.00,4.14,6.74$ and $8.04 \mathrm{~g} / 100 \mathrm{~g}$ respectively. The weaning diets were nutritionally adequate in terms of protein, $\mathrm{Fe}$ and $\mathrm{Zn}$. Utilization of unripe banana fortified with crab may provide adequate nutrient needed for growth and development of young children.
\end{abstract}

Key words: Complementary feeding, food fortification, weaning food, unripe banana, young and infant child feeding.

\section{INTRODUCTION}

Adequate child nutrition and health care during the first several years of life is a fundamental pillar of health, growth and development in children (Dewey et al., 2001).

It is well recognized that the period from birth to two years of age is a "critical window" for the promotion of optimal growth: in health, mental and in behavior. Exclusive breastfeeding has been scientifically proven to be perfect food from at least an hour after birth until six months because it contains all the nutrients and immunological factors required for optimal health and growth. The WHO recommends exclusive breastfeeding till six months of age, and continued breastfeeding for at least two years along with timely introduction of adequate amount of complementary foods of suitable nutritional quality (UNICEF, 2013).

Globally, inappropriate complementary feeding practices have been identified as a determinant of diarrheal disease, malnutrition outcomes and under- 5 mortality (NPoPC and ICF International, 2014). In Nigeria, complications from malnutrition remain a major health problem with prominent levels of stunting (37\% wasting (18\%) and underweight (12\%) in infants and young children (NPoPC and ICF International, 2014)

Commercially prepared weaning foods in a developing country like Nigeria are relatively expensive and out of reach of the majority of care givers. However, mothers and care givers usually prepare weaning foods from locally available food staples such as corn, guinea corn, cowpea, millet, sorghum, banana and these are characterized by low protein energy density (Nwamarah and Amadi, 2009). A very good first food to give a baby, along with breast milk, is a soft, thick, creamy porridge, made from the staple food of the community. Every community has a main staple food. It is often the first food that people think of when asked about their diet. The staple food contains starch, and it is eaten by most of the people in the community at most meal. It is usually less expensive than other types of food. The staple varies from country to country. It may be rice, wheat, maize, cassava, yam, banana etc. In rural areas, families will probably spend a lot of their time growing storing and cooking the staple food. Generally, in Nigeria, Ogi (pap) is a traditional weaning food usually prepared at the household level (Nwamarah and Amadi, 2009). In Akwa Ibom state, documented information on types of weaning foods used by mothers are few (Eka et al, 2010) with no consideration of their nutrient content and suitability or otherwise.

www.scirj.org

(C) 2021, Scientific Research Journal

http://dx.doi.org/10.31364/SCIRJ/v9.i01.2021.P0121836

This publication is licensed under Creative Commons Attribution CC BY. 
Unripe banana, one of the staples has been used in the local preparation of weaning food in Nigeria especially in communities of Akwa Ibom and Cross River States (Adepoju and Etukumoh, 2014). The unripe banana porridge (Otor mboro in Efik/Ibibio language) is usually prepared at the household level by mothers and care givers. Unripe banana flour has been reported to contain $4.14 \mathrm{~g} / 100 \mathrm{~g}$ protein, $0.45 \mathrm{~g} / 100 \mathrm{~g}$ lipids and $86.92 \mathrm{~g} / 100 \mathrm{~g}$ carbohydrate (Menezes et al., 2011). Reports have shown that most of the local weaning foods are in most cases poor in nutrient density. Often times, they are gruels based on cereals and starchy tubers and are poor in protein content (Elsa and Ceasar, 2000). This has been implicated in the etiology of protein energy malnutrition usually manifested as nutritional marasmus and kwashiorkor.

There is therefore need to supplement traditional weaning foods with affordable protein sources. Crabs, for example have been reported to be very rich in proteins $(21.4 \mathrm{~g} / 100 \mathrm{~g})$ and essential amino acids (Williams et al., 2016). Crab ingests and accumulates omega 3 fatty acids through the food chain algae and phyto-plankton, the primary producers of omega 3 fatty acids. Crab constitutes one of the main sources of animal protein most especially among coastal dwellers and is abundantly available in some parts of Nigeria including Akwa Ibom state (Elegbede and Fashina- Bombata, 2013). This study evaluated the effects of crab meat in unripe banana based complementary food.

\section{MATERIALS AND METHODS}

\section{Sample collection}

Fresh matured lively specimens of Callinetes amnicola (blue crab) were purchased from fishermen at the landing site of the Great Kwa River in April 2017. The specimens were placed in an ice chest and immediately transported to the Research laboratory in the Department of Medical Biochemistry, University of Nigeria, Enugu Campus.

\section{Collection and Treatment of Samples}

Fresh matured lively specimens of Callinetes amnicola (blue crab) were purchased from fishermen at the landing site of the Great Kwa River in April 2017 and placed in an ice chest, taken to the Department of Zoology and Environmental Biology, University of Calabar for authentication and immediately transported to the Research laboratory in the Department of Medical Biochemistry, University of Nigeria, Enugu Campus. The unripe banana (Musa sapientum) fingers were procured from farmers in Atan Offot, Uyo and identification was done at the Botany Department, University of Calabar. Then, taken to the Research Laboratory were it was washed with distilled water, peeled, grated, boiled and dried at $51^{\circ} \mathrm{C}$ for $24 \mathrm{hrs}$, then milled and stored in a refrigerator at $-4^{\circ} \mathrm{C}$ prior analyses. Crab samples will be stepped in hot distilled water at a temperature of $60^{\circ} \mathrm{C}$ for $5 \mathrm{~min}$ to remove all dirt. The appendages and digestive system was removed from the body and the edible portion taken separately. The edible portion (crab meat) was kept in an electric oven at $51^{\circ} \mathrm{C}$ for $24 \mathrm{hrs}$ for proper drying. The dried samples was milled and stored in a refrigerator at $-4^{\circ} \mathrm{C}$ until analyses. Cerelac ${ }^{\circledR}$, a commercial weaning food, was procured from a super market in Enugu metropolis.

\section{Formulation of diet}

The experimental diets were formulated as follows:

Diet I: Cerelac ${ }^{\circledR}$ as Standard

Diet II: $100 \%$ unripe banana

Diet III: $10 \%$ Crab meat $+90 \%$ Unripe banana meal $\left(\mathrm{UBCM}_{1}\right)$

Diet IV: $15 \%$ Crab meat $+85 \%$ Unripe banana meal $\left(\mathrm{UBCM}_{2}\right)$

Diet V: $10 \%$ Cray fish $+90 \%$ Unripe banana meal (UBCF)

\section{Proximate analyses}

The proximate composition was determined by the method of the Association of Official Analytical Chemists (AOAC, 2003). Moisture content was taken as the weight loss after drying $2 \mathrm{~g}$ of each fresh body part to a constant weight at $87-98^{\circ} \mathrm{C}$ with the aid of an electric oven (Astell Heason, England) for $24 \mathrm{hrs}$. Crude protein was determined by the micro-Kjeldahl method in which the total nitrogen in the sample was estimated and subsequently multiplied by a factor of 6.25 . Fat content was obtained by acid hydrolysis and intermittent extraction with petroleum ether (B. P. 40-60 ${ }^{\circ}$ ) using Soxhlet apparatus (Corning, England). Ash was determined by dry ashing or by measuring the residue left after incineration of a weighed portion of the sample at $600^{\circ} \mathrm{C}$ for 10 hours using a muffle furnace. Crude fibre was estimated by boiling the sample with $1.25 \%(\mathrm{w} / \mathrm{v})$ sulphuric acid and then with $1.25 \%$ (w/v) sodium hydroxide and incinerating the residue at $550^{\circ} \mathrm{C}$; the loss in weight represented the crude fibre content of the sample (AOAC, 2003$)$. Total carbohydrate content was obtained by difference after subtracting the protein, fat and ash from the total dry matter, expressed in percentage.

Determination of energy value

www.scirj.org

(C) 2021, Scientific Research Journal

http://dx.doi.org/10.31364/SCIRJ/v9.i01.2021.P0121836

This publication is licensed under Creative Commons Attribution CC BY. 
The caloric value, expressed as kcal/g of each sample was calculated using the Atwater factors for protein, fat, and carbohydrate (FAO/WHO, 1998). Accordingly, the amount of protein obtained by chemical analysis was multiplied by 4 , fat was multiplied by 9 , and digestible carbohydrate was multiplied by 4 . Energy was calculated as the sum of the three values. That is, Energy $=[$ protein $(\mathrm{x} 4)$ + fat $(\mathrm{x}$ 9) + carbohydrate (x 4)] kcal/g.

\section{Determination of mineral elements}

Elemental composition was analyzed using the solution obtained by dry-ashing the samples at $550^{\circ} \mathrm{C}$ and dissolving in distilled water with a few drops of concentrated hydrochloric acid in a volumetric flask. Sodium (Na) and potassium (K) were measured with a Corning U.K. Model 405 flame photometer (AOAC, 2003) while iron (Fe), zinc ( $\mathrm{Zn})$, magnesium $(\mathrm{Mg})$ and calcium $(\mathrm{Ca})$ were obtained spectrophotometrically (AOAC, 2003)

\section{Preparation of the porridge}

The processed unripe banana were stirred into hot water containing already steamed $100 \mathrm{~g}$ crab meat and $100 \mathrm{~g}$ cray fish in two different pot and left on the gas cooker to simmer for $5 \mathrm{mins}$. 30ml Palm oil, $5 \mathrm{~g}$ pepper and salt was added to taste. The porridge was stirred well and stored in a food flask. The Cerelac was stirred into cold water and allowed to simmer for 5 mins. The resulting porridge was also stored in a food flask prior to sensory evaluation.

\section{Sensory evaluation}

The sensory evaluation of the porridges was conducted at primary health centre, Idu Uruan, Akwa Ibom State. A panel of twenty nursing mothers/ caregivers was selected by random sampling to evaluate the samples using a nine point hedonic scale where 9 was the highest and 1 the lowest score. The degrees of likeness were as follows: 9 - Like extremely; 8 - Like very much; 7 - Like moderately; 6 - Like slightly; 5 - Neither like nor dislike; 4 - Dislike slightly; 3 - Dislike moderately; 2 - Dislike very much and 1 Dislike extremely.

The crab meat fortified unripe banana porridge and cray fish fortified unripe banana porridge and cerelac were presented to each panelist as coded in the hedonic scale. Each panelist was served in coded plates with spoons and a cup of clean water to rinse the mouth after each tasting to avoid bias. The samples were evaluated by each panelist for flavour, texture, colour, taste, consistency and general acceptability.

\section{Focused Group Discussion:}

This section of the study was qualitative hospital based cross sectional descriptive survey of parameters for acceptability of unripe banana-based weaning food fortified with crab among caregivers of under-5 in Offot community in Uyo LGA, Akwa Ibom State. The FGD session was conducted by a moderator and the note taking and time keeping was done by the assistant moderator. Also tape recorder was used to record the FGD sessions. The note taker observed and took down the note. The audio recording was transcribed and the data analysis was done using deductive approach.

Sample size: 30 Caregivers of U-5 were purposively selected for establishing the parameters for acceptability study within the study location.

Sampling Technique: Three health facilities were purposively selected. Ten Caregivers per health facility attending nutrition clinic were selected.

Inclusion criteria: Caregivers of U-5 domiciled in the study area and must have been registered in Nutrition Clinics in the health facilities.

Pre-test of data collection tools: Moderator sample questions, note-taker's and Observer's guidelines were pre-tested in PHC, Idu Uruan, a similar health facility

\section{Data Analysis}

All data were expressed as Mean \pm SD. The data was analyzed by one way ANOVA with post hoc least significant difference equal variances assumed using the IBM SPSS statistic software version 22 (SPSS: Statistical Package for Social Sciences) Differences at $p$ $<0.05$ were considered significant. Manual handling of data was done for FGDs using deductive approach in consideration of, that is, thematic area of predetermined framework.

Ethical considerations: Ethical approval was obtained from the University of Nigeria Teaching Hospital (UNTH) Ituku - Ozalla, Enugu and the Uyo LGA Health Authority. Informed consents were sought from all the caregivers of under-5 children for voluntary participation.

\section{RESULTS AND DISCUSSIONS}

www.scirj.org

(C) 2021, Scientific Research Journal

http://dx.doi.org/10.31364/SCIRJ/v9.i01.2021.P0121836

This publication is licensed under Creative Commons Attribution CC BY. 
Table 1 presents the proximate composition of the crab fortified unripe banana weaning diet. The fortified unripe banana had higher protein, moisture and fat, lower in ash, carbohydrate and crude fiber.

Table 2 presents the minerals composition per $100 \mathrm{~g}$ of the formulated diets compared to unfortified unripe banana meal.Table 3 present the mean scores of sensory attributes of the porridges made from blend of unripe banana puree/crab meat and cray fish .The results showed that $\mathrm{UBCM}_{2}$ had a higher but non - significant $(\mathrm{p}>0.05)$ taste score $(8.85 \pm 0.2)$ than the standard $(8.80 \pm 0.2)$ and UBCF $(7.90 \pm 0.4)$. The colour of $\mathrm{UBCM}_{2}$ had a higher mean score $(7.30 \pm 0.4)$ compared to UBCF $(7.20 \pm 0.4)$. The consistency of UBCF $(7.80 \pm 0.4)$ was similar ( $>>0.05)$ to that of Standard $(7.70 \pm 0.2)$. General acceptability of cerelac $(7.65 \pm 0.2)$ was scored highest but this was statistically similar $(\mathrm{p}<0.05)$ to $\mathrm{UBCM}_{1}(7.60 \pm 0.5)$.

The high protein content of crab meat can be attributed to facts that sea foods generally are good sources of protein. This was similar to the results reported by Kathirvel et al (2014). Thus, a small quantity of crab meat would increase the nutritive value of the unripe banana meal to a considerable extent. The high protein content (8.04\%) of Fortified banana 15\% CM is as a result of 5\% increase in crab meat of $15 \%$ fortified compared to $10 \%$ fortified unripe banana meal $(6.74 \%)$.

The variation in fat content of the samples may be as a result of their sources. Crab ingests and accumulates omega-3 fatty acid through the food chain, algae and phytoplankton (Elegbede and Fashina- Bombata, 2013). Starch is the main form of carbon storage in unripe banana and banana is low in fat. The fat content of unripe banana was $1.09 \mathrm{~g}$, this is higher than the $0.2 \mathrm{~g} / 100 \mathrm{mg}$ reported by Menezes et al, (2011). Numerous studies on crab revealed similar values of fat content, Udo Paul and Vivian are recorded $0.45 \%$ of lipid level in the flesh of C. amnicola (Udo and Arazu, 2012)

The higher sodium level in the $15 \%$ fortified sample $(35.99 \mathrm{mg})$ as compared to the unfortified is in accordance with the research conducted by Ijarotimi and Olopade (2009). Sodium, 169.46mg quantity of mineral was found in crab meat and it was found that unripe banana is very low in sodium $(12.42 \mathrm{~g})$ but when fortified with crab, the $\mathrm{Na}$ content increases to $35.99 \mathrm{mg}$ with $15 \%$ crab meat fortification and $28.12 \mathrm{mg}$ with $10 \%$ crab meat. Fe has quite a lot of vital functions in the human body. Iron deficiency occurs when the demand for iron is high, in this present study, the iron level of crab meat was $20.85 \mathrm{mg}$. This was higher than the RDI $7 \mathrm{mg}$ adequate intake per day for infant and young child. The fortification of unripe banana with crab boosts the iron content up to $4.62 \mathrm{mg}$, a level near the RDI. However, it is recommended that the vegetables should be added in the preparation of the weaning food to complement the differences in iron.

Zinc deficiency primarily caused by a diet low in animal product and high in phytate. A level of $5.30 \mathrm{mg}$ of zinc was reported in crab meat which is very close to the RDI of $5.5 \mathrm{mg}$ but in the fortified unripe banana (10\% and $15 \%)$, the zinc content drop to $1.09 \mathrm{mg}$ and $1.31 \mathrm{mg}$ respectively. The Calcium content was found to be higher across the samples. This value was higher than that reported by Wheaton and Lawson (1985).

The results of the FGDs revealed that the respondents gave three major reasons: cost, availability and their familiarity of the raw materials why they will use locally sourced raw material for preparing weaning food, although majority of the respondents were of the view that the cost of the raw materials that will be used to prepare weaning food for their children will be the key determinant in using them:

$$
\text { “...if what I need to prepare the weaning food is affordable, I will gladly use it... }
$$

Some of the respondents asserted emphatically that even though the cost is paramount, the raw material should be available all year round so that nursing mothers can have access to it whenever there is need for them to prepare weaning food:

"if I must use any kind of food for the preparation of weaning food for my baby, I will first of all consider the cost of the product, then I will now ensure that one can find it in the market to buy or it is grown locally. There is no point of constantly changing a particular product, especially when the baby is familiar with it".

The familiarity of a certain food type is essence, as it plays vital role in using it to prepare weaning food for their babies:

“...well, I cannot use food that I am not familiar with or that is not known in my area to prepare weaning food for my baby. If I must prepare special weaning food for my baby, it must be the one I know very well..."

Traditional practice of weaning mentioned by participants during discussion was porridge unripe banana and pap, which they have been using overtime to wean their babies. Although very few can afford packaged weaning food (e.g. Nutrend and Cerelac) while others depend on the aforementioned food type. There was no identified cultural and religious prohibition on the use of unripe banana and crab. Crab has been a source of food for the locals and also unripe banana:

www.scirj.org

(C) 2021, Scientific Research Journal

http://dx.doi.org/10.31364/SCIRJ/v9.i01.2021.P0121836

This publication is licensed under Creative Commons Attribution CC BY. 
"there is no such belief..., we are familiar with the food (respondent smile)..."

Also, the key issue raised during discussion hinged on scientific evidence (evidence based) of it being healthy, nutritional value and how it can sustain baby. Majority were concerned about scientific evidence of it being healthy and the nutritional value:

"if scientifically proven to show that it is good, I can use it".

However, majority of the respondents prefers that the weaning food be made by mothers or caregivers instead of commercially prepared, sold in the market. Their concern was hygiene and possibly other preservatives:

"I prefer doing it myself because of hygiene. I don't trust these commercial ones because they can add chemical in the name of preservative".

While some were of the opinion that they would prefer products:

"I prefer buying it from the market, if available because if I want to prepare it myself very well, it will waste my time..."

Consequently, several issues were raised as factors that will encourage the use of processed unripe banana fortified with crab. They are availability, cost, familiarity, nutritional value and availability of technology for preparing the weaning food in the order of decreasing frequency. The respondent were of the opinion that if the raw materials required for its production is available at an affordable price, it should be food materials they are familiar with, which should contain all the necessary nutrients required for the growth and development of their baby and there should be available equipment that can be operated and repaired by the locals, should it break down in the course of usage:

"I will use it if the unripe banana and crab are available or if commercial products are always available. I wouldn't want to be changing weaning food frequently..." "I will use if it is cheap".

"I will use it if it is nutritious, I have a lot of banana in my farmyard".

Although, very few of the respondents were of the opinion that they will not use processed unripe banana fortified with crab, majority were willing to use it anytime anywhere.

\section{CONCLUSION}

Unripe banana based weaning foods are of low protein content and may result in increased childhood malnutrition among under-5 children in Akwa Ibom State. However, supplementing with crab meat increases the protein and micronutrient contents required for optimal growth and development for infants. Crab is cheaper and affordable and when added in the adequate proportion can compare positively with the commercially available complementary foods among caregivers both in nutrient quality and acceptability. Efforts should therefore be made to popularize the use of crabmeat as supplement in local unripe banana complementary foods used in infant feeding.

\section{ACKNOWLEDGEMENT}

We wish to acknowledge the technical support received from Network on Behavioral Research and Child Survival in Nigeria (NETBECSIN). We are profoundly grateful to all the caregivers who volunteered to participate in this study. Special thanks are due to Head of Offot Community Health Center for logistic support.

\section{REFERENCES}

Adepoju, O.T and Etukumoh, A .U (2014) Nutrient Composition and suitability of four commonly used local complementary Foods in Akwa Ibom State, Nigeria. African Journal of Food, Agriculture Nutrition and Development 14(7).

AOAC (2003) Association of Official Analytical chemists. Official methods of analysis AOAC International, Gaithersburg, MD. USA

Dewey, K. G., Cohen, R. J., Brown, K. H and Landa, R.L (2001). Effects of exclusive breastfeeding for 4 versus 6months on maternal nutritional status and infant motor development: results of two randomized trials in Honduras. Journal of Nutritional Science; 131:262-7.

www.scirj.org

(C) 2021, Scientific Research Journal

http://dx.doi.org/10.31364/SCIRJ/v9.i01.2021.P0121836

This publication is licensed under Creative Commons Attribution CC BY. 
Eka B. E., Abeey W. B and Akaninwor J. O (2010) Nutritive evaluation of some traditional weaning foods from Akwa Ibom State. Nigeria Journal of Biochemistry and Molecular Biology 25(1): 65 - 72.

Elegbede I O, Fashina- Bombata HA (2013) Proximate and Mineral composition of Common crab Species (Callinetes Pallidas and Cardisoma Armatum) of Badagry Creek, Nigeria. Poultry Fish Wildlife Science 2:110-116.

Elsa R. J, Caesar G.V (2000). Complementary Feeding. Journal Of Pediatrics; 76:253.

FAO/WHO (1998) Preparation and use of Food - Based Dietary Guidelines. Report of a joint FAO/WHO Consultation. WHO Technical Report series 880 Geneva.

Ijarotimi O.S and Olopade A.J(2009) Determination of Amino Acid content and protein Quality of Complementary food produced from locally available food materials in Ondo State, Nigeria. Malaysian Journal of Nutrition 15(1):87-95.

Kathirvel K, Eswar A, Manikandarajan T, Ramamoorthy K, Sankar G (2014) Proximate composition, amino acid, Fatty acid and mineral analysis of box crab, Calappa Lophus from parangipettai, southeast coast of India. Jenvir Science \& Toxicology \& Food Tech 8:50 -57.

Menezes, E.W., Tadini, C. C., Tribess, T. B., Zuleta, A., Binaghi J( 2011) Chemical Composition and nutritional value of unripe banana flour(Musa acuminata). Plant Foods Human Nutrition 66:231.

Moore S \& Stein W. H (1963). Chromatographic amino acids determination by the use of automatic recording equipment. Methods Enzymology 6: 819-831

National population commission (NPopC)/ ICF International. (2014), Nigeria Demographic and Health survey 2013. Abuja, Nigeria and Rockville, Maryland, USA: NPopC and ICF International.

Nwamarah, J.U And Amadi, V.O (2009) Chemical and Sensory Evaluation of complementary food for infants using locally made Nigeria staples. Nigeria Journal of Nutritional Science Vol. 30(1) 112 -114.

Udo, P. J and Arazu, V. N(2012) The proximate and mineral composition of two edible crabs Callinetes amnicola and Uca tangeri of Cross River, Nigeria. Paskistan Journal of Nutrition 11(1) :78-82

UNDP (2012) Summary of Child Survival Partnership, The Nutrition Challenge in Sub-Saharan Africa, Regional Bureau for Africa . The Lancet under nutrition series, 2008

United Nation Children's Fund, Improving child nutrition. The achievable imperative for global progress. New York, USA: United Nation Children Fund, 2013

UNICEF (2007) Global Study on Child Poverty and Disparities 2007-2008 Guide. Global Policy Section, Division of Policy and Planning. New York.

Williams 1.O, Ekpeyong E, Lawal O, Essien N.C, Edemumoh T. O (2016) Nutrient and energy composition of flesh, Limbs and carapace of Callinetes amnicola from Great Kwa river, South East Nigeria. Africa Journal Food Science \& Tech 7(3); 60 -65.

WHO (1998) Complementary Feeding of young children in developing countries: a review of current scientific knowledge. WHO Geneva, Switzerland. p 1-245.

WHO and UNICEF (2009) WHO Child growth standards and the identification of severe acute malnutrition in infants and children, A Joint Statement.

Wheaton, F. W and Lawson, T .B, Processing aquatic food products, USA : John Wiley and Sons, 1985

www.scirj.org

(C) 2021, Scientific Research Journal

http://dx.doi.org/10.31364/SCIRJ/v9.i01.2021.P0121836

This publication is licensed under Creative Commons Attribution CC BY. 
Table I: Proximate composition of fortified and unfortified unripe banana meal $(\mathrm{g} / 100 \mathrm{~g})$

\begin{tabular}{lcccc}
\hline Nutrient & Crab Meat & $\mathbf{1 0 0 \% ~ U B}$ & UBCM $_{\mathbf{1}}$ & UBCM $_{2}$ \\
Carbohydrate & $49.28 \pm 0.02$ & $76.14 \pm 0.34$ & $74.35 \pm 1.15(2.4 \downarrow)$ & $75.57 \pm 0.43(0.7 \downarrow)$ \\
Protein & $26.00 \pm 0.71$ & $4.14 \pm 0.07$ & $6.74 \pm 0.08(63 \uparrow)$ & $8.04 \pm 0.02(94.2 \uparrow)$ \\
Fat & $6.10 \pm 0.07$ & $1.09 \pm 0.1$ & $2.02 \pm 0.06(85.3 \uparrow)$ & $2.08 \pm 1.30(90.8 \uparrow)$ \\
Ash & $7.27 \pm 0.00$ & $5.50 \pm 0.06$ & $2.04 \pm 0.11(62.9 \downarrow)$ & $2.01 \pm 0.01(63.5 \downarrow)$ \\
Crude Fibre & $5.56 \pm 0.08$ & $8.49 \pm 0.67$ & $6.83 \pm 0.03(54.9 \downarrow)$ & $5.92 \pm 0.05(30.3 \downarrow)$ \\
Moisture & $5.37 \pm 0.23$ & $5.39 \pm 0.32$ & $5.32 \pm 0.24(1.3 \downarrow)$ & $5.38 \pm 0.03(0.19 \downarrow)$ \\
Energy(Kcal) & 322.1 & 330.23 & $342.54(3.7 \uparrow)$ & $353.16(6.9 \uparrow)$
\end{tabular}

Values are expressed Mean \pm SD of 3 independent determinations. Figures in parenthesis indicate percentage increases $(\uparrow)$ or decreases ( $\downarrow$ ) with supplementation. UB: Unripe banana; $\mathrm{UBCM}_{1}$ : Unripe banana 90\%, Crab Meat 10\% UBCM 2 : Unripe banana $85 \%$, Crab Meat $15 \%$

Table II: $\quad$ Estimated amounts of mineral element $(\mathrm{mg})$ provided by $100 \mathrm{~g}$ of the composite samples

\begin{tabular}{ccccc}
\hline Nutrient & Crab Meat & Unripe Banana & UBCM $_{\mathbf{1}}$ & UBCM $_{\mathbf{2}}$ \\
$\mathrm{Na}$ & $169.46 \pm 0.01$ & $12.42 \pm 0.02$ & $28.12 \pm 0.02(126 \uparrow)$ & $35.99 \pm 0.01(190 \uparrow)$ \\
$\mathrm{K}$ & $27.09 \pm 0.01$ & $17.35 \pm 0.0$ & $18.12 \pm 0.01(43 \uparrow)$ & $21.82 \pm 0.01(26 \uparrow)$ \\
$\mathrm{Ca}$ & $106.30 \pm 0.02$ & $15.70 \pm 0.10$ & $24.84 \pm 0.01(58.2 \uparrow)$ & $29.41 \pm 0.14(87 \uparrow)$ \\
$\mathrm{Mg}$ & $33.42 \pm 0.13$ & $12.92 \pm 0.02$ & $14.98 \pm 0.01(15.9 \uparrow)$ & $16.02 \pm 0.01(24 \uparrow)$ \\
$\mathrm{Fe}$ & $20.85 \pm 0.01$ & $0.70 \pm 0.10$ & $3.12 \pm 0.02(346 \uparrow)$ & $4.63 \pm 0.01(561 \uparrow)$ \\
$\mathrm{Zn}$ & $5.30 \pm 0.10$ & $0.60 \pm 0.20$ & $1.09 \pm 0.01(82 \uparrow)$ & $1.33 \pm 0.03(122 \uparrow)$ \\
$\mathrm{Cu}$ & $0.18 \pm 0.02$ & $0.30 \pm 0.10$ & $0.17 \pm 0.01(43 \downarrow)$ & $0.20 \pm 0.10(33 \downarrow)$ \\
$\mathrm{Mn}$ & $0.16 \pm 0.01$ & $0.04 \pm 0.01$ & $0.03 \pm 0.01(25 \downarrow)$ & $0.06 \pm 0.02(50 \uparrow)$
\end{tabular}

Values are expressed Mean \pm SD of 3 independent determinations. Figures in parenthesis indicate percentage increases ( $\uparrow)$ or decreases $(\downarrow)$ with supplementation. UB: Unripe banana; $\mathrm{UBCM}_{1}$ : Unripe banana 90\%, Crab Meat 10\% UBCM 2 : Unripe banana 85\%, Crab Meat $15 \%$ 
Table 3: Sensory Scores of porridges made from unripe banana flour fortified with crabmeat and crayfish compared with Cerelac ${ }^{\circledR}$

\begin{tabular}{lcccc} 
Characteristic & CERELAC $^{\circledR}$ & UBCM $_{1}$ & UBCM $_{2}$ & UBCF \\
Taste & $8.80 \pm 0.2^{\mathrm{a}}$ & $6.80 \pm 0.2^{\mathrm{a}}$ & $8.85 \pm 0.2^{\mathrm{a}}$ & $7.90 \pm 0.4^{\mathrm{c}}$ \\
Texture & $7.05 \pm 0.2^{\mathrm{a}}$ & $6.95 \pm 0.3^{\mathrm{a}}$ & $7.10 \pm 0.3^{\mathrm{a}}$ & $7.00 \pm 0.3$ \\
Colour & $7.10 \pm 0.3^{\mathrm{a}}$ & $7.25 \pm 0.3^{\mathrm{a}}$ & $7.30 \pm 0.4^{\mathrm{bc}}$ & $7.20 \pm 0.4^{\mathrm{c}}$ \\
Flavour & $7.30 \pm 0.3^{\mathrm{a}}$ & $7.40 \pm 0.2^{\mathrm{a}}$ & $7.45 \pm 0.2^{\mathrm{a}}$ & $7.50 \pm 0.2^{\mathrm{a}}$ \\
Consistency & $7.70 \pm 0.2^{\mathrm{a}}$ & $7.10 \pm 0.3^{\mathrm{b}}$ & $7.15 \pm 0.6^{\mathrm{b}}$ & $7.80 \pm 0.4^{\mathrm{c}}$ \\
G/Acceptability $7.65 \pm 0.2^{\mathrm{a}}$ & $7.20 \pm 0.1^{\mathrm{a}}$ & $7.25 \pm 0.1$ & $7.60 \pm 0.5^{\mathrm{b}}$ \\
\hline
\end{tabular}

Means with the same superscripts along the row are not significantly different $(\mathrm{p}>0.05)$

Cerelac ${ }^{\circledR}$ (Standard); $\mathrm{UBCM}_{1}$ : Unripe Banana $90 \%$, Crab meat $10 \%$ and Palm oil; $\mathrm{UBCM}_{2}$ : Unripe Banana $85 \%$, Crab Meat $15 \%$ and Palm oil; UBCF: Unripe Banana $90 \%$, Cray Fish 10\% and Palm oil. 